\title{
SPACE ANGELS: ANGELOLOGY IN C. S. LEWIS'S COSMIC TRILOGY
}

Anjos do espaço: angelologia na trilogia cósmica de C. S. Lewis

Are not all angels ministering spirits sent to serve those who will inherit salvation?

Heb $1,14^{*}$

Carlos Ribeiro Caldas Filho **

ABSTRACT: The Northern Irish author C. S. Lewis (1898-1963) was one of the outstanding Christian thinkers of the last century. A prolific author, he moved through different areas, such as literary criticism, youth literature, science fiction, and texts of theological exposition and of apologetics. In science fiction there is his remarkable "Cosmic Trilogy": Beyond the Silent Planet, Perelandra, and That Hideous Strength. In these three books, Lewis presents a vast array of themes. Among these is angelology,the systematic study of heavenly beings known as angels. The aim of this article is to present the major influences that Lewis used to build his angelology: old Jewish literature, exemplified in texts such as the Ethiopian Enoch (or the Book of Enoch or First Enoch), and the biblical tradition itself. The article will seek also to defend the hypothesis that, using fiction, Lewis builds an imaginative and suggestive theology that is a critique of the rationalism of continental theology of his day.

KEYWORDS: Angelology. Lewisian Studies. Science Fiction. Theology and Literature.

RESUMO: O escritor norte-irlandês C. S. Lewis (1898-1963) foi um dos mais destacados pensadores cristãos do século passado. Autor de vasta obra, transitou por áreas como crítica literária, literatura infanto-juvenil, ficção científica e textos de

\footnotetext{
* Unless another version of the Bible is mentioned, all the biblical references in this article are from the New International Version (NIV), a Protestant version of the Bible.

** Pontifical Catholic University of Minas Gerais State, Belo Horizonte, Minas Gerais, Brasil.
} 
exposição teológica e apologética propriamente. Na categoria ficção científica destaca-se a assim chamada "Trilogia Cósmica": Além do planeta silencioso, Perelandra e Aquela fortaleza medonha. Nestes três livros Lewis apresenta grande gama de temas. Dentre tantos, a angelologia - o estudo sistematizado dos seres celestiais conhecidos como anjos. O objetivo do presente artigo é apresentar as principais influências que Lewis utilizou para construir sua angeologia, literatura judaica antiga, representada por textos como o Enoque Etíope (ou Livro de Enoque ou 1Enoque) e a tradição bíblica. Procurar-se-á também defender a hipótese que, com o recurso da literatura de ficção, Lewis constrói uma teologia imaginativa e sugestiva que é uma crítica ao racionalismo da teologia continental de seu tempo.

PALAVRAS-CHAVE: Angelologia. Estudos lewisianos. Ficção científica. Teologia e literatura.

\section{Introduction}

$\mathrm{T}_{\mathrm{s}}$ he Northern Irish author Clive Staples Lewis (1898-1963), or simply C. S. Lewis, was one of the main Christian authors of the late century. A prolific author, he moved through areas such as literary criticism, youth literature, science fiction and texts of theological exposition and apologetics. In these works, Lewis presented an imaginative theology, sometimes as fantasy and sometimes as fiction. His ingenuity is clearly demonstrated by the fact he wrote in such a varied array of literary styles. No wonder his books have been translated into dozens of languages and are still being published. In his works, Lewis dealt with theological subjects such as Angelology, which in Systematic Theology is the study of the heavenly beings known as angels. It was not common to speak about such a matter in the mid-last century. Continental European theology of his day, characterized by a strong rationalistic tendency, had difficulty in presenting any elaboration about invisible beings that, apparently at least, has more to do with ancient mythologies than the concerns of "modern" man. As "swimming against the tide", Lewis presented a curious and sophisticated angelology in his main works of fiction and fantasy, viz., his cosmic trilogy: Out of the Silent Planet, Perelandra, and That Hideous Strength. This article will examine the way Lewis presented an angelology in this trilogy.

\section{Angelogia in the Bible - A Synthesis}

This part of the article will present, as its subheading indicates, a synthesis of the biblical teaching about the angelological theme. Curiously, "angelology is not a great theme in Christian theology, in spite of so many 
references to angels in the Bible" (COMFORT, ELWELL, 2001, p. 47). In fact, angelology is a weak, or even nonexistent, chapter in contemporary systematic theologies because of a conscious or unconscious rationalistic influence that is not comfortable with invisible creatures. Such creatures have no place when one understands the world only through rationalistic and mechanist perspectives.

If this is a problem to modern man (and perhaps to postmodern man too) it was not to the man of the Middle Ages and of the classical Greco-Roman, Middle Eastern, Sub-Saharan Africa, or Indian Subcontinent, or of the Americas or East Asian antiquity. Karl Barth reminds us that the Christian symbols affirm belief in God the Father Almighty, Creator, not only of Earth, but of the heavens as well. According to Barth,

Heaven is a part of creation that is incomprehensible to man, who is able to understand only earth. I join myself to the Symbol of Nicaea, which speaks about the invisibilia et visibilia". I tried to take these two expressions: "visible and invisible things" for the expressions understandable and understandable. When Scripture - and we are here using its terminology, speaks about heaven, it does not understand simply what we are used to name this way, viz., the atmospheric sky, but a created reality which has an absolute dominion over our purely physical sky.. The man of old, especially the inhabitant of the Near East, thought about the visible world as entirely covered by an enormous dome called firmament. This dome was, as far as he was concerned, the beginning of the invisible and celestial dominion (BARTH, 1968, p. 92-93, our translation, emphasis of the author).

The "invisible and celestial dominion" identified by Barth is inhabited by all kinds of angelical beings. Barth does not mention angels in the chapter in which he comments on the meaning of the article of the Creed that declares that God the Father created "heaven." However, considering that Barth was one of the few outstanding theologians of the last century who considered this theme in his theological construction, it is reasonable to assert that, even though he did not mention angels explicitly, he had them in mind when he discussed that article of the Creed ${ }^{2}$.

The word angel, whose Latin form is angelus ${ }^{3}$, has a Greek origin: $\ddot{\alpha} \gamma \gamma \varepsilon \lambda \mathrm{o}$ ("ángelos"), and means "messenger." ${ }^{4}$ Ángelos is the word used by the

\footnotetext{
${ }^{1}$ (Things) visible and invisible.

${ }^{2}$ This article will not discuss the way Barth dealt with the theme of angelology. For more details about this, see, inter alia, LINDSAY (2017, p. 1-18).

${ }^{3}$ The Vulgate uses angelus to refer to heavenly messengers, and nuntius (the root of the word nuncio) to refer to human messengers (BROMILEY in ELWELL (1988, p. 72).

${ }^{4}$ REBLIN (2011, p. 63) presents a comprehensive list of all biblical references of the verb "send" and to the noun "messenger" (human or heavenly).
} 
LXX to translate the Hebrew מלאך - malach, "messenger", in the sense of "emissary" or "courier", one who delivers a message (SCHÖKEL, 1997, p. 376-377). Angels are often mentioned in the Bible and take up considerable space not only in Judeo-Christian tradition, but in Islam also ${ }^{6}$. As a matter of fact, as stated by Kenyan theologian James NkansahObrempong, "belief in beings with spiritual powers is an ideal present in many cultures all over the world" (NKANSAH-OBREMPONG, 2018, p. 19).

The Western portrait of an angel as a winged-man, wearing a white tunic and with markedly Caucasian features is very well known. In the same way, Christian art and iconography have ever dedicated much attention to such celestial beings. However, these popular portraits of angels are not always (or never) faithful to what biblical texts say about them. According to American Bible scholar Steven Cox, "the Bible offers few descriptions of heavenly messengers because the focus is on the message, not on the Messenger" (COX, 2018, p. 83). Lewis, some decades before Cox, had made a curious and shrewd remark about this matter. Even though it is long, it deserves to be quoted:

It should be (but it is not) unnecessary to add that a belief in angels, whether good or evil, does not mean a belief in either as they are represented in art and literature. Devils are depicted with bats' wings and good angels with birds' wings, not because anyone holds that moral deterioration would be likely to turn feathers into membrane, but because most men like birds better than bats. They are given wings at all in order to suggest the swiftness of unimpeded intellectual energy. They are given human form because man is the only rational creature we know. Creatures higher in the natural order than ourselves, either incorporeal or animating bodies of a sort we cannot experience, must be represented symbolically if they are to be represented at all.

These forms are not only symbolical but were always known to be symbolical by reflective people. The Greeks did not believe that the gods were really like the beautiful human shapes their sculptors gave them. In their poetry a god who wishes to "appear" to a mortal temporarily assumes the likeness of a man. Christian theology has nearly always explained the "appearance" of an angel in the same way. It is only the ignorant, said Dionysius in the fifth century, who dream that spirits are really winged men.

\footnotetext{
${ }^{5}$ From malach comes מלאכי - malachi, "my messenger", that is, the messenger of Yaweh, the title of Malachi, one of the Twelve Prophets in the Hebrew Bible, the books known the Christian tradition as "Minor Prophets". There is no agreement among the Bible scholars if malachi is the name of the prophet or if it is a title that has to do with the task of the messenger, the spokesman that announces the content of the book. If this last option is the right one, the identity of the malach is unknown.

${ }^{6}$ An example of this is Azrael, the angel of death in the Jewish tradition, known as Azra'il in the Islamic tradition.
} 
In the plastic arts, these symbols have steadily degenerated. Fra Angelico's angels carry in their faces and gestures the peace and authority of Heaven. Later come the chubby infantile nudes of Raphael; finally, the soft, slim, girlish, and consolatory angels of nineteenth century art, shapes so feminine that they avoid being voluptuous only by their total insipidity - the frigid houris of a testable paradise. They are a pernicious symbol. In Scripture the visitation of an angel is always alarming; it has to begin by saying "Fear not." The Victorian angel looks as if it were going to say, "There, there." (LEWIS, 1982, p. 7).

Lewis's statement is a sort of introduction to his The Screwtape Letters, and it reveals a perceptive observation. Human language has obvious limitations to speak about realities that belong to a non-physical order. Therefore, the only possible way to make reference to situations and beings from a metaphysical dimension is through comparisons and suggestions taken from the material world. Lewis was very accurate commenting on this issue in the aforementioned excerpt of his book.

The Bible suggests the existence of kinds or categories of celestial beings: besides the angel it makes reference to the seraf (שרף), whose plural form is seraphim, quoted only in Is 6.2, 6, to the cherub (כדןב), whose plural form is cherubim (Gn 3.24; $1 \mathrm{Kg} \mathrm{6.29,} \mathrm{32,} \mathrm{35;} \mathrm{Ez} \mathrm{10,} \mathrm{passim),} \mathrm{and} \mathrm{to}$ the sar hamalachim (שרהמלאכים), literally "prince (or "chief") of angels," translated sometimes as archangel (from the Latin archangelus). Archangels Michael and Gabriel': are mentioned only in later texts of the Hebrew Bible, specifically in apocalyptic Michael (מיכאל in the Hebrew Bible, and Mıх $\alpha \eta \dot{\lambda}$ in the Septuagint and in the New Testament), is mentioned in Dn 10.13, 21; 12.1; Jd 9; Rev 12.7 (there is also a reference to an "archangel" in 1 Tes 4.16, however, no personal name is mentioned in this Pauline text), and Gabriel (לאיךבג in the Hebrew Bible, mentioned in Dan 9.21; $\Gamma \alpha \beta \varrho ı \eta \lambda$ in the Septuagint and twice in the New Testament, Lk 1.19, 26).

There is also a reference to the mysterious angel of the face, מלארהפנים, malach hapanim, the angel of the presence, who is probably alluded to in Ex 33.14 and explicitly mentioned in Is 63.9. These texts are very difficult to translate. A quick comparison of several different translations makes it clear that the translators had great difficulty in understanding the phrasing of such verses:

\footnotetext{
${ }^{7}$ Raphael ("God heals") is mentioned in Tobiah 5, a deuterocanonical text.
} 


\begin{tabular}{|c|c|c|}
\hline Versão da Bíblia & Ex 33.14 & Is 63.9 \\
\hline $\begin{array}{l}\text { American Standard } \\
\text { Version }\end{array}$ & $\begin{array}{l}\text { And he said, My presence } \\
\text { shall go with thee, and } \\
\text { I will give thee rest. }\end{array}$ & $\begin{array}{l}\text { In all their affliction he was } \\
\text { afflicted, and the angel of } \\
\text { his presence saved them }\end{array}$ \\
\hline Complete Jewish Bible & $\begin{array}{l}\text { He answered, "Set your } \\
\text { mind at rest - my } \\
\text { presence will go with you, } \\
\text { after all." }\end{array}$ & $\begin{array}{l}\text { In all their troubles he was } \\
\text { troubled; then the Angel of } \\
\text { His Presence saved them }\end{array}$ \\
\hline $\begin{array}{l}\text { 21st Century King James } \\
\text { Version }\end{array}$ & $\begin{array}{l}\text { And He said, "My presence } \\
\text { shall go with thee, and I } \\
\text { will give thee rest." }\end{array}$ & $\begin{array}{l}\text { In all their affliction } \mathrm{He} \\
\text { was afflicted, and the angel } \\
\text { of His presence saved them }\end{array}$ \\
\hline Wycliffe Bible & $\begin{array}{l}\text { And God said, My face } \\
\text { shall go before thee, and I } \\
\text { shall give rest to thee. }\end{array}$ & $\begin{array}{l}\text { In all the tribulation of } \\
\text { them. It was set in } \\
\text { tribulation, and the angel of } \\
\text { his face saved them. }\end{array}$ \\
\hline The Message & $\begin{array}{l}\text { GOD said, "My presence } \\
\text { will go with you. I'll see } \\
\text { the journey to the end." }\end{array}$ & $\begin{array}{l}\text { In all their troubles, he was } \\
\text { troubled, too. He didn't } \\
\text { send someone else to help } \\
\text { them. He did it himself, in } \\
\text { person. }\end{array}$ \\
\hline Easy-To-Read Version & $\begin{array}{l}\text { The Lord answered, "I } \\
\text { myself will go with you. } \\
\text { I will lead you." }\end{array}$ & $\begin{array}{l}\text { He sent his special angel } \\
\text { to save them }\end{array}$ \\
\hline Good News Translation & $\begin{array}{l}\text { The LORD said, "I will go } \\
\text { with you, and I will give } \\
\text { you victory." }\end{array}$ & $\begin{array}{l}\text { From all their suffering. It } \\
\text { was not an angel, but } \\
\text { the LORD himself who } \\
\text { saved them }\end{array}$ \\
\hline Geneva Bible (1599) & $\begin{array}{l}\text { And he answered, My } \\
\text { presence shall go with thee, } \\
\text { and I will give thee rest. }\end{array}$ & $\begin{array}{l}\text { In all their troubles he was } \\
\text { troubled, and the Angel of } \\
\text { his presence saved them }\end{array}$ \\
\hline $\begin{array}{l}\text { Revised Standard } \\
\text { Version }\end{array}$ & $\begin{array}{l}\text { And he said, "My presence } \\
\text { will go with you, and I will } \\
\text { give you rest." }\end{array}$ & $\begin{array}{l}\text { In all their affliction he was } \\
\text { afflicted, and the angel of } \\
\text { his presence saved them; }\end{array}$ \\
\hline New Living Translation & $\begin{array}{l}\text { The LORD replied, "I will } \\
\text { personally go with you, } \\
\text { Moses, and I will give you } \\
\text { rest-everything will be } \\
\text { fine for you." }\end{array}$ & $\begin{array}{l}\text { In all their suffering he also } \\
\text { suffered, and he personally } \\
\text { rescued them. }\end{array}$ \\
\hline
\end{tabular}




\begin{tabular}{|l|l|l|}
\hline $\begin{array}{l}\text { New International } \\
\text { Version }\end{array}$ & $\begin{array}{l}\text { The LORD replied, "My } \\
\text { Presence will go with you, } \\
\text { and I will give you rest." }\end{array}$ & $\begin{array}{l}\text { In all their distress he too } \\
\text { was distressed, and the } \\
\text { angel of his presence saved } \\
\text { them }\end{array}$ \\
\hline Orthodox Jewish Bible & $\begin{array}{l}\text { And He said, My Presence } \\
\text { shall go with thee, and I } \\
\text { will give thee rest. }\end{array}$ & $\begin{array}{l}\text { In all their tzoros He was } \\
\text { afflicted, and the malach of } \\
\text { His presence saved them }\end{array}$ \\
\hline New English Translation & $\begin{array}{l}\text { And the LORD said, "My } \\
\text { presence will go with you, } \\
\text { and I will give you rest." }\end{array}$ & $\begin{array}{l}\text { Through all that they } \\
\text { suffered, he suffered too. } \\
\text { The messenger sent from } \\
\text { his very presence } \\
\text { delivered them. }\end{array}$ \\
\hline
\end{tabular}

These several translations of the Bible seem to indicate an angel that represents the presence of Yahweh, but sometimes they seem to indicate Yahweh himself. Jewish tradition identifies the angel of the face by the name Metatron, and there is no consensus if there is one kind of "angel of the face" and Metatron is the main one, or if Metatron is the only angel that contemplates the face of the Eternal.

Still regarding a classification of angels, the aforementioned Nkansah-Obrempong adds: "Paul mentions an angelical hierarchy that includes thrones, dominions, powers and principalities responsible for some issues related to men and the world. He condemns the adoration of angels and proclaims that Christ is superior to cosmic powers" (NKANSAH-OBREMPONG, 2018, p. 22). Reasoning in a similar way, English theologian Geoffrey Bromiley states:

Based on several statements regarding the nature of angels and the use Paul makes of the terms "principalities", "authorities", "thrones", "dominions" and "powers", early and medieval theology developed a complex and speculative explanation of the angelical world. Pseudo-Dionisius understood them as separate entities, and united them as seraphim, cherubim, archangels and angels, in a triplex hierarchy of nine choirs. Aquinas, the Doctor Angelicus, adopted a similar scheme in his full and pervasive discussion, but his focus was more on the nature of angels as spiritual, spatial and individual entities, primarily occupied with the work of enlightenment and capable of rational demonstration (Summa contra Gentiles, 91; Summa Theologica, 50-64).

According to Calvin, the mistake in so much angelology was to deal with the issue of angels apart from the biblical witness (BROMILEY, 1988, p. 74).

Having presented this brief summary of the theme of angels in the Bible I will now present some thoughts about the literary aspect of science fiction and, after this, the plot of Lewis's cosmic trilogy and finally, how angelology is presented in the three books. 


\section{Science fiction as a literary category}

Science fiction has antecedents in Jules Verne (1828-1905) and H. G. Wells (1886-1946). As a literary genre, science fiction is "akin", so to speak, to fantasy literature, or heroic fantasy. One of the main representatives of such genre in the last century is John R. R. Tolkien, with all his legendarium, whose more well-known works are The Silmarillion, The Hobbit and the trilogy The Lord of the Rings. There is also some similarity to narratives of the Sword and Sorcery style, whose main representative is American author Robert Howard, creator of Kull, The Conqueror and of the very well-known Conan, the Barbarian. Gothic and horror fiction and gothic horror could be included as akin somehow to science fiction literature. Literary criticism is unanimous in identifying appoint Mary Shelley's Frankenstein or the Modern Prometheus (popularly known only as Frankenstein), published in 1818, as the very first work of such genre. Dracula, by the Irish author Bram Stoker, in the end of 19th century, is another well-known representative of this genre ${ }^{8}$.

It is a consensus among literary critics that That Hideous Strength (from now on, THS) and indeed all Lewis's cosmic trilogy are works of science fiction, due to their classical themes, such as space voyages and encounters with intelligent extraterrestrial beings. Starting from this point, a question is raised: what kind of literature is science fiction? TAVARES (1986, p. 11) informs us that "Science fiction was the sound and nice name chosen by Hugo Gernsback, editor of the Amazing Stories magazine in the 20's for the kind of literature he was trying to incite".

There is a distinction between hard science fiction and soft science fiction: the first is concerned with the scientific aspects of the story, trying to present them with verisimilitude, and the other does not have such a concern. The ideal reader of csoft science fiction is not concerned with technical details: to this reader, the story in itself is what matters. According to Bráulio Tavares,

Science seems to be a source of inspiration, but we will not find - except in a very few cases - a presence of compelling scientific reasonings. A science fiction author is comfortable imagining the most whimsical phenomena, and to "theorize" its existence in two or three phrases, and that's all [...] one button is pressed and one character is vaporized or is sent to another galaxy, or becomes a vegetable. How does it happen? The author does not give too many explanations: he/she says that it is the "X 26 ray" or it is a "teletransporter" or a "molecular converter" - and it is all (TAVARES, 1986, p. 8).

\footnotetext{
${ }^{8}$ For more details from the perspective of literary theory about fantasy literature, its subdivisions and variations, see TODOROV (2012).
} 
Such description is important for the purposes of this article, because it also indicates a consensus that Lewis's cosmic trilogyis a softscience fiction. In other words:

We must remember that science fiction uses science as its raw material, but it manipulates the instruments of fiction itself. As a result, its commitment is not to truth, but rather to imagination and fantasy. A good science fiction story is one able to show us a universe different from our own and by and large one that is more complex, and give it a proper coherence. This will guarantee the conditions to produce good fiction, that is, to tell a good story, a story that leaves a strong impression and makes us think (TAVARES, 1986, p. 24).

It is exactly this kind of literature that is found in THS. To quote the Brazilian science fiction researcher Bráulio Tavares once more:

Science fiction is a transversal literature, communication channel that interconnects cybernetics and surrealism, humor and nuclear physics and so on to the infinite [...] In the literary field this division manifests itself through the termshard science fiction andsoft science fiction. The first deals with themes belonging to fields such as physics, chemistry, astronautics, etc. The second has to do with fields like psychology, anthropology, social sciences, etc. (TAVARES, 1986, p. 73-74, author's emphasis).

To the examples given by Tavares in soft science fiction it is possible to add, in the case of Lewis's cosmic trilogy, theology. Lewis is by no means concerned with technical details in his narrative. In chapter 4 of Out of the Silent Planet, Lewis has Weston describe the spacecraft that leads to Mars to a thunder-stricken Ransom. The description is ingenious, but it is not technical

The ship is roughly spherical, and now that we are outside the gravitational field of the Earth, "down" means _and feels _towards the centre of our own little metal world. This, of course, was foreseen and we built her accordingly. The core of the ship is a hollow globe we keep our stores inside it - and the surface of that globe is the floor we are walking on. The cabins are arranged all round this, their walls supporting an outer globe which from our point of view is the roof. As the centre is always "down", the piece of floor you are standing on always feels flat or horizontal and the wall you are standing against always seems vertical. (LEWIS, 2005a, p. 29-30).

It is imperative to highlight that Lewis was an assiduous reader - and a critical one - of science fiction. He was a contemporary of great names of a literary genre, such as Arthur C. Clarke, Ray Bradbury, Aldous Huxley, George Orwell, David Lindsay and H. G. Wells. He was not only a contemporary of these authors, but an experton their works. In a lecture delivered at the English Club of the University of Cambridge in November 24, 1955 (cf. HOOPER, 2018, p. 27) ${ }^{9}$, Lewis presented his perspective on science

\footnotetext{
${ }^{9}$ Walter Hooper (b. 1931) was a private secretary to Lewis and became the literary advisor of Lewis's estate, regarding Lewis's copyright.
} 
fiction, making it clear that he wrote a kind of fiction that was neither hard nor soft science fiction. In Lewis's words,

In this kind of story, the pseudo-scientific apparatus is to be taken simply as a 'machine' in the sense which that word bore for the Neo-Classical critics. The most superficial appearance of plausibility - the merest sop to our critical intellect-will do. I am inclined to think that frankly supernatural methods are best. I took a hero once to Mars in a space-ship, but when I knew better I had angels convey him to Venus. Nor need the strange worlds, when we get there, be at all strictly tied to scientific probabilities. It is their wonder, or beauty, or suggestiveness that matters. When I myself put canals on Mars I believe I already knew that better telescopes had dissipated that old optical delusion. The point was that they were part of the Martian myth as it already existed in the common mind. The defense and analysis of this kind are, accordingly, no different from those of fantastic or mythopoeic literature in general. But here sub-species and sub-sub-species break out in baffling multitude. The impossible-or things so immensely improbable that they have, imaginatively, the same status as the impossible-can be used in literature for many different purposes. I cannot hope to do more than suggest a few main types: the subject still awaits its Aristotle (LEWIS, 2017a, p. 96-97).

As a matter of fact, Lewis was a critic of both hard and soft science fiction, and he forged his own version of this literary genre. Criticizing soft science fiction, Lewis declared:

In this sub-species the author leaps forward into an imagined future when planetary, sidereal, or even galactic travel has become common. Against this huge backcloth he then proceeds to develop an ordinary lovestory, spy story, wreckstory, or crimestory. This seems to me tasteless (LEWIS, 2017b, p. 84-45).

These quotations by Lewis reveals that he was a great expert in the science fiction produced in his time, and that at the same time he was fully aware of the fiction he himself produced. For Lewis, science fiction is not morally neutral, nor is it mere entertainment. It will not be an overstatement to declare that he produced a science fiction that had a theological purpose as will be shown in this article.

Literary criticism uses the expression space opera to name a particular kind of science fiction that has as its main representatives Flash Gordon and, more recently, the Star Wars saga. Lewis does not use the expression, but it is clear that he despised this kind of fiction.

English biologist J. B. S. Haldane, who was Marxist and therefore did not believe in the transcendent or in any metaphysical possibility, in 1946 criticized Lewis's cosmic trilogy exactly because of its "weak science". Lewis presented a response to Haldane. At one point, he stated:

It certainly is an attack, if not on scientists, yet on something which might be called scientism - a certain outlook on the world which is casually connected with the popularisation of the sciences (...)It is, in a word, the belief that the 
supreme moral end is the perpetuation of our own species, and that this is to be pursued even if, in the process of being fitted for survival, our species has to be stripped of all those things for which we value it-of pity, of happiness, and of freedom (LEWIS, 2017c, p. 109).

Lewis criticizes the myth of progress, evolutionism understood only in a material way, without any transcendent perspective, technology and science as ends in themselves, science "without soul", so to speak, concerned only with what is material, believing the ends justify the means, as it is ruled by a purely evolutionist and developmentalist perspective. And he presents his beliefs using fiction literature as the vehicle for his convictions. In fact, his cosmic trilogy is not entirely soft, but it is a kind of mix of soft science fiction and literature of the marvelous, a particular kind of literature that was very common in classical antiquity, not only Greco-Roman, but Middle Eastern and Far Eastern as well, and during all the medieval period.

After this presentation, even in short, of science fiction as literature we can go on presenting an analysis of the angelology in Lewis's cosmic trilogy, especially in THS.

\section{Lewis's cosmic trilogy - Synthesis of the plot}

In 1958, in the beginning of the space race between the former Soviet Union and the United States ${ }^{10}$, Lewis wrote an article called Will We Lose God in Outer Space? In this article, Lewis presents his thoughts about the existence of intelligent life in other planets and, in a positive case, if those specimens would be affected by the fall, that had taken place on Earth. He asserted that there would be no problem at all for Christians if the existence of intelligent creatures in other planets was confirmed one day.

What Lewis presented in a theoretical way in Will We Lose God in Outer Space? will be presented in the shape of fantasy literature in his cosmic trilogy. As it was observed by Lewis scholar David Downing,

The books of the trilogy are deceptively simple [...] Out of the Silent Planetas a cosmic voyage, Perelandra as an Edenic fantasy and That Hideous Strength as a satire of the modern academy (DOWNING, 1995, p. 5-6).

The plot of the trilogy can be summarized as follows: it is a story about Elwin Ransom, philologist at Cambridge University ${ }^{11}$, who was deceived and

${ }^{10}$ The space race had its beginning one year before, when the Soviets launched the famous space rocket Sputnik, taking on board the likewise famous bitch Laika, which could not stand the rigors of the space voyage.

${ }^{11}$ The fact that Ransom is a philologist is an obvious homage paid by Lewis to his friend John R. R. Tolkien, who was a philologist. 
kidnapped by the physicist Dr. Weston and by Mr. Dick Devine, a friend of Weston. When Ransom recovers consciousness (Weston and Devine had drugged him, giving him a drink with narcotics) he realizes that something that seemed impossible was taking place: the three of them were on board of a spacecraft, and they were outside the atmosphere of the Earth. After a month in the space, they land in an unknown planet. Ransom succeeds in escaping from his captors, and after wandering aimlessly he discovers that there is intelligent life in that planet: creatures with which he will be able to communicate using his skills as a philologist. Ransom will find out that all the planets in the Field of Arbol (our solar system) are submissive to Maleldil, the creator and sustainer of all things and of all realities, both visible and invisible. For the purpose of this article, it can be observed that Maleldil does not rule directly. He does so through the Oyaresu, that in turn command the eldila, and all other creatures ${ }^{12}$. The most important part of the books presents a dialogue between Weston and the Oyarsa of Malacandra. In this dialogue, Weston defends with ardor the idea of the "Law of the strongest": if the Tellurians (we, the inhabitants of Planet Earth) are stronger than the Malacandrians, they have the right to subjugate, and even to annihilate them. The Oyarsa thwarts Weston's and Devine's plans of conquest, and sends them back to Earth, along with Ransom.

The narrative of Perelandra takes place not so long after the adventures described in the first book. Now Ransom is sent back to space by order of the Oyarsa of Malacandra. However, his destination is not Mars, but Venus, called Perelandra in the language of the Field of Arbol. Once there, Ransom discovers a world that makes him remember the Garden of the Hesperides of Greek mythology. The omniscient narrator of the book presents Ransom's thoughts that Earth's mythologies are perhaps echoes of a distant past, of an epoch not untainted by disobedience to the Creator. Modern rationalist mind rejects myth, but perhaps its language is more appropriate than scientific language to express some truths about life. Perelandra is a world where lands float and there is only one ban from the Creator: never go to the only one dry land of the planet. Ransom learns there is a humanoid couple who rule over Perelandra: King Tor and Queen Tinidril. Ransom learns also that Weston is there, working as an emissary of the Bent Oyarsa of Earth. Perelandra presents the narrative of the three first chapters of Genesis, with one difference.

Finally, in That Hideous Strength the great saga will be concluded. Differently from the two previous books, the narrative takes place entirely on Earth. The last book is much larger and more complex that the two others.

\footnotetext{
${ }^{12}$ Such a vision of a heavenly hierarchy and of angelical beings that work in the cosmos as intermediate of the supreme divine being comes from Jewish apocalyptic literature. For more details see, inter alia, MELVIN (2013, p. 7, 9).
} 
Ransom enters the scene just in the second half of the narrative, and the book takes a while to present a link with the two previous. In this third book there are two narratives, running in parallel with each other: in one, the story of Jane and Mark, a young married couple living a deep crisis in their relationship, and in the other, the NICE - National Institute of Co-ordinated Experiments - an octopus-like organization, which has ambitious plans to take over all English society and, after this, the whole world. It will be shown that they want to bring the legendary Merlin, the Magician of the Arhurian myth, back to life. As a matter of fact, Merlin has been for more than one thousand years in a state of suspended animation. Therefore, there are two groups opposed to each other: on one hand, NICE, where Mark is trying to ascend in his professional career at any cost, but at the same time in fear of the things he sees there and one the other hand, Ransom himself. Merlin is awakened from his sleep of many centuries and to everyone's surprise, takes Ransom's side in the fight against NICE. At the end, six Oyaresu come down to Earth to prevent the plans of NICE, because its leaders were summoning evil spiritual powers. The trilogy ends with the total defeat of NICE, Ransom going again to Perelandra (this time, for good) and the restoration of Jane'sand Mark's marriage.

\section{Angelology in the cosmic trilogy}

How is the theme of angelology presented in the cosmic trilogy? That is what this session of the article intends to present.

Lewis in Perelandra uses the literary device to insert himself into the narrative, and to hear the report that Ransom himself gives him. Lewis learns from Ransom that there is much more life in space than he ever thought. One must observe that Lewis does not refer to outer space as sky, but as Deep Heaven. The word heaven can be understood as "sky", meaning "firmament", but it also has the theological meaning of "paradise". Lewis in his cosmic trilogy plays with the two possible meanings of the word. In Out of the Silent Planet, Lewis describes Ransom inthe spacecraft that will take him and his captors to Malacandra/Mars thinking that heavenis the more appropriate word to refer to outer space:

But Ransom, as time wore on, became aware of another and more spiritual cause for his progressive lightening and exultation of heart. A nightmare, long engendered in the modern mind by the mythology that follows in the wake of science, was falling off him. He had read of 'Space': at the back of his thinking for years had lurked the dismal fancy of the black, cold vacuity, the utter deadness, which was supposed to separate the worlds. He had not known how much it affected him till now that the very name 'space' seemed a blasphemous libel for this empyrean ocean of radiance in which they swam. 
He could not call it 'dead'; he felt life pouring into him from it every moment. How indeed should it be otherwise, since out of this ocean the worlds and all their life had come? He had thought it barren; he saw now that it was the womb of worlds, whose blazing and innumerable offspring looked down nightly even upon the Earth with so many eyes - and here, with how many more! No, space was the wrong name. Older thinkers had been wiser when they named it simply the heavens - the heavens which declared the glory ${ }^{13}$ - the happy climes that ly Where day never shuts his eye Up in the broad fields of the sky. He quoted Milton's words to himself lovingly, at this time and often ${ }^{14}$ (LEWIS, 2005a, p. 34-35).

The basic premise of Lewis's cosmic trilogy is this: all the planets in our Solar System, called Field of Arbol (= the Sun) are inhabited by intelligent beings. There is one only language, "Old Solar" (Hlab-Eribol-ef-Cordi, LEWIS, 2019 b, p. 22) spoken in all Field of Arbol. In the trilogy the planets are called Viritrilbia (Mercury), Perelandra (Venus), Thulcandra (Earth), Sulva (Earth's Moon), Malacandra (Mars), Glundandra (Jupiter), Lurga (Saturn) andNeruval (Uranus) ${ }^{15}$. Each one of the planets is ruled by a tutelary angel, representing Maleldil, the supreme deity. This tutelary angel is called Oyarsa. There is the Oyarsaof Malacandra, the Oyarsa of Perelandra, and so on. The name of the each Oyarsais the name of the planet, and vice-versa: Malacandra is the Oyarsa of Malacandra, Perelandra is the Oyarsa of Perelandra, and so on. In Out of the Silent Planet (from now on, OSP), Lewis shows Ransom able to understand a little bit of Old Solar presenting what he had understood about the archon of Malacandra:

Ransom asked who Oyarsa was. Slowly, and with many misunderstandings, he hammered out the information that Oyarsa (i) lived in Meldilorn; (2) knew everything and ruled everyone; (3) had always been there; and (4) was not a hross, nor one of the séroni ${ }^{16}$ (LEWIS, 2005a, p. 82-83).

Using the aforementioned literary device to put himself into the narrative, Lewis presents the source from which he drew the concept of Oyarsa:

This is where I come into the story. I had known Dr. Ransom slightly for several years and corresponded with him on literary and philological subjects, though we very seldom met. It was, therefore, quite in the usual order of things that I should write a letter some months ago, of which I will quote the relevant paragraph. It ran like this: 'I am now working at the Platonists of the twelfth

\footnotetext{
${ }^{13}$ Allusion to Psalm 19.1.

${ }^{14}$ John Milton's poem quoted by Lewis is: happy climes that ly, Where day never shuts his eye Up in the broad fields of the sky (LEWIS, 2005a, p. 35).

${ }^{15}$ Seven planets are mentioned, and this is not coincidence, because there were seven planets known for observation with naked eye in antiquity and the medieval period. Neptune and Pluto were discovered only after the invention of the telescope.

${ }^{16}$ Hross and séroni are two of the intelligent creatures of Malacandra in OSP.
} 
century and incidentally discovering that they wrote damnably difficult Latin. In one of them, Bernardus Silvestris, there is a word I should particularly like your views on - the word Oyarses. It occurs in the description of a voyage through the heavens, and an Oyarses seems to be the "intelligence" or tutelary spirit of a heavenly sphere, i.e., in our language, of a planet. I asked C. J. about it and he says it ought to be Ousiarches. That, of course, would make sense, but I do not feel quite satisfied. Have you by any chance ever come across a word like Oyarses, or can you hazard any guess as to what language it may be?' (LEWIS, 2005a, p. 196).

After this, Lewis adds: "We have found reason to believe that the medieval Platonists were living in the same celestial year as ourselves - in fact, that it began in the twelfth century of our era - and that the occurrence of the name Oyarsa (Latinized as oyarses) in Bernardus Silvestris is not an accident (LEWIS, 2005a, p. 197, author's emphases).

In each planet there are the eldila (plural form of eldil), invisible, intangible and intelligent beings that serve the Oyarsa. The inhabitants of each planet are able to see the eldila. Lewis, with the typical English wit and fine sense of humor (even though he was North Irish), explains the eldila, the "space angels":

For Ransom had met other things in Mars besides the Martians. He had met the creatures called eldila, and specially that great eldil who is the ruler of Mars or, in their speech, the Oyarsa of Malacandra. The eldila are very different from any planetary creatures. Their physical organism, if organism it can be called, is quite unlike either the human or the Martian. They do not eat, breed, breathe, or suffer natural death, and to that extent resemble thinking minerals more than they resemble anything we should recognize as an animal. Though they appear on planets and may even seem to our senses to be sometimes resident in them, the precise spatial location of an eldil at any moment presents great problems. They themselves regard space (or 'Deep Heaven') as their true habitat, and the planets are to them not closed worlds but merely moving points - perhaps even interruptions - in what we know as the Solar System and they as the Field of Arbol (LEWIS, 2005a, p. 209-210).

Earth is the only planet that breaks with such pattern, as it is under the rule the Oyarsa known as The Bent One, that rebelled against Maleldil. Since then there is no more contact or exchange of any kind between Thulcandra and the other planets of the Field of Arbol. Thulcandra, the Earth, became the "silent planet" that gives title to the first book of the trilogy. In Malacandra (Mars) Ransom finds out three kinds of hnau, that is, living sentient beings: the hrossa, the sorns (séroni plural form) and the pfifltriggi. Weston and Devine want to explore the mineral riches of the planet and conquer its creatures, annihilating them, if necessary.

In a very curious dialogue between Ransom and Hyoi (one of the intelligent Malacandrian beings), Lewis presents the eldila through Ransom's perspective: 
'Hyoi,' he said, 'it comes into my head that when I first saw you and before you saw me, you were already speaking. That was how I knew that you were hnau, for otherwise I should have thought you a beast, and run away. But who were you speaking to?' 'To an eldil.' 'What is that? I saw no one.' 'Are there no eldila in your world, Hman?' That must be strange.' 'But what are they?' 'They come from Oyarsa - they are, I suppose, a kind of hnau.' 'As we came out today, I passed a child who said she was talking to an eldil, but I could see nothing.' 'One can see by looking at your eyes, Hman, that they are different from ours. But eldila are hard to see. They are not like us. Light goes through them. You must be looking in the right place and the right time; and that is not likely to come about unless the eldil wishes to be seen. Sometimes you can mistake them for a sunbeam or even a moving of the leaves; but when you look again you see that it was an eldil and that it is gone. But whether your eyes can ever see them I do not know. The séroni would know that.' (LEWIS, 2005a, p. 93-94).

In another very interesting dialogue, Lewis presents Ransom talking to one of the séroni, considered as one of the most wise creatures of Malacandra. The dialogue is too long, but it is important to reproduce it in order to achieve a comprehension of how Lewis understood the angelical beings:

'And Oyarsa - is he a sorn?' 'No, no, Small One. I have told you he rules all nau' (so he pronounced hnau) 'and everything in Malacandra.' 'I do not understand this Oyarsa,' said Ransom. 'Tell me more.'

'Oyarsa does not die,' said the sorn. 'And he does not breed. He is the one of his kind who was put into Malacandra to rule it when Malacandra was made. His body is not like ours, nor yours; it is hard to see and the light goes through it.' 'Like an eldil?'

'Yes, he is the greatest of eldila who ever come to a handra.'

'What are these eldila?'

'Do you tell me, Small One, that there are no eldila in your world?'

'Not that I know of. But what are eldila, and why can I not see them? Have they no bodies?'

'Of course they have bodies. There are a great many bodies you cannot see. Every animal's eyes see some things but not others. Do you not know of many kinds of body in Thulcandra?'

Ransom tried to give the sorn some idea of the terrestrial terminology of solids, liquids and gases. It listened with great attention.'

That is not the way to say it,' it replied. 'Body is movement. If it is at one speed, you smell something; if at another, you hear a sound; if at another, you see a sight; if at another, you neither see nor hear nor smell nor know the body in any way. But mark this, Small One, that the two ends meet.' 
'How do you mean?'

'If movement is faster, then that which moves is more nearly in two places at once.'

'That is true.'

'But if the movement were faster still - it is difficult, for you do not know many words - you see that if you made it faster and faster, in the end the moving thing would be in all places at once, Small One'.

'I think I see that.'

'Well, then, that is the thing at the top of all bodies so fast that it is at rest, so truly body that it has ceased being body at all. But we will not talk of that. Start from where we are, Small One. The swiftest thing that touch es our senses is light. We do not truly see light, we only see slower things lit by it, so that for us light is on the edge - the last thing we know before things become too swift for us. But the body of an eldil is a movement swift as light; you may say its body is made of light, but not of that which is light for the eldil. His "light" is a swifter movement which for us is nothing at all; and what we call light is for him a thing like water, a visible thing, a thing he can touch and bathe in - even a dark thing when not illumined by the swifter. And what we call firm things flesh and earth - seems to him thinner, and harder to see, than our light, and more like clouds, and nearly nothing. To us the eldil is a thin, half-real body that can go through walls and rocks; to himself he goes through them because he is solid and firm and they are like cloud. And what is true light to him and fills the heaven, so that he will plunge into the rays of the sun to refresh himself from it, is to us the black nothing in the sky at night. These things are not strange, Small One, though they are beyond our senses. But it is strange that the eldila never visit Thulcandra.'

'Of that I am not certain,' said Ransom. It had dawned on him that the recurrent human tradition of bright, elusive people sometimes appearing on the Earth - alns, devas and the like - might after all have another explanation than the anthropologists had yet given. True, it would turn the universe rather oddly inside out; but his experiences in the space-ship had prepared him for some such operation (LEWIS, 2005a, p. 116-119, author's emphases).

\section{Influences on Lewis's cosmic angelology}

How did Lewis build his angelology? What are the main influences in his thought concerning such theme? These are the questions that will be answered in this session of the article. Fortunately for the 
researcher, Lewis himself wrote in a comprehensive and detailed way about his main sources, not only about angelology, but to his worldview as well. He did so in The Discarded Image, published posthumously, in whichis described his understanding about Medieval and Renaissance literature ${ }^{17}$. Among so many different subjects, there is also a view of the cosmos as a whole, and its beings as well. One can say that in The Discarded Image Lewis reveals from the source from which he extracted what he used creatively in a literary shape in his cosmic trilogy. To prove this point it will be presented in a quotation from The Discarded Image that, although long, is important to understand how Lewis built the angelology in his cosmic trilogy.

In the Middle Ages four books (The Celestial Hierarchies, The Ecclesiastical Hierarchies, The Divine Names and the Mystical Theology) were attributed to that Dionysius who was converted by hearing St Paul's address to the Areopagus. This attribution was disproved in the sixteenth century [...]. His writings are usually regarded as the main channel by which a certain kind of Theology entered the Western tradition [...]. It is by his angelology that he contributed to the Model, and we can therefore confine our attention to his Celestial Hierarchies. Our author differs from all earlier and some later authorities by declaring the angels to be pure minds (mentes), unembodied. In art, to be sure, they are represented as corporeal pro captu nostro, as a concession to our capacity (i). And such symbolism, he adds, is not degrading, ' for even matter, deriving its existence from the true Beauty, has in the fashion of all its parts some traces ofbeauty and worth' (ii). This statement, in a book which came to be so authoritative, may be taken as proof that educated people in the Middle Ages never believed the winged men who represent angels in painting and sculpture to be more than symbols.

It was pseudo-Dionysius whose arrangement of the angelic creatures into what Spenser calls their ' trinall triplicities', into three 'Hierarchies' containing three species each, was finally accepted by the Church.

The first Hierarchy contains the three species, Seraphim, Cherubim, and Thrones. These are the creatures closest to God. They face Him $\alpha \mu \varepsilon \dot{\sigma} \sigma \varsigma$ nullius interiectu, with nothing between, encircling Him with their ceaseless dance ${ }^{18}$. The names of Seraph and Throne are both associated by this author with ideas of heat or burning; a characteristic well known to the poets. Hence Chaucer's sonmour ${ }^{19}$ had 'a fyr-reed cherubirmes face', and it was not only for rhyme's sake that Pope wrote ' the rapt Seraph that adores and burns'.

\footnotetext{
${ }^{17}$ One must remember that Lewis was a medievalist, during all his academic career as a professor of Medieval and Renaissance Literature in both Oxford and Cambridge. It is also necessary to remember the Judeo-Christian tradition, which forged his thought in a decisive way.

${ }^{18}$ Lewis uses this Pseudo-Dionysius' idea of a "great dance" in the last chapter of Perelandra, describing such dance in praise to Maleldil, the Criador, Sustentador amd Redeemer of the cosmos (LEWIS, 2005b, p. 260-282).

${ }^{19}$ The word somnour is from Middle English (from the 11th to 15th centuries), and corresponds to the word summoner in contemporary English. It means literally "the one who summons".
} 


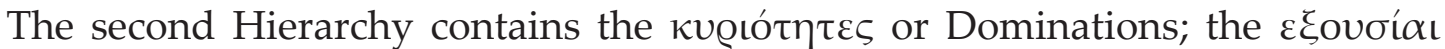

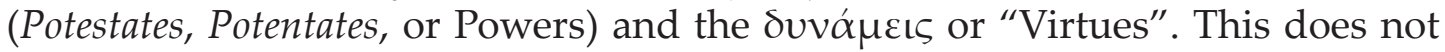
mean moral excellences but rather 'efficacies', as when we speak about the 'virtues' of a magic ring or a medicinal herb.

The activity of both these Hierarchies is directed towards God; they stand, so to speak, with their faces to Him and their backs to us. In the third and lowest Hierarchy we at last find creatures who are concerned with Man. It contains Princedoms (or Principalities, or Princes); Archangels; and Angels. The word angel is thus both a generic name for all the nine species contained in the three Hierarchies, and also a specific name for the lowest - as sailor in English sometimes includes all seafaring persons and is sometimes confined only to those who berth forward.

Princedoms are the guardians and patrons of nations, so that Theology names Michael the Prince of the Jews (ix). The scriptural source of this is Dan. xii. 1.[...]The two remaining species, Archangels and Angels, are the 'angels' of popular tradition, the beings that 'appear' to human individuals.

They are indeed the only superhuman beings that do so, for pseudo-Dionysius is as certain as Plato or Apuleius that God encounters Man only through a ' mean', and reads his own philosophy into scripture as freely as "mean" [...] His God does nothing directly that can be done through an intermediary; perhaps prefers the longest possible chain of intermediaries; devolution or delegation; a finely graded descent of power and goodness, is the universal principle. The Divine splendor (illustratio) comes to us filtered, as it were, through the Hierarchies [... ]

The total angelic creation is a mean between God and Man [...].

The spirit of this scheme, though not every detail, is strongly present in the Medieval Model. And if the reader will suspend his disbelief and exercise his imagination upon it even for a few minutes, I think he will become aware of the vast readjustment involved in a perceptive reading of the old poets. He will find his whole attitude to the universe inverted. In modern, that is, in evolutionary, thought Man stands at the top of a stair whose foot is lost in obscurity; in this, he stands at the 74 Selected Materials: the Seminal Period bottom of a stair whose top is invisible with light. He will also understand that something besides individual genius (that, of course) helped to give Dante's angels their unrivalled majesty. Milton, aiming at that, missed the target. Classicism had come in between. His angels have too much anatomy and too much armour, are too much like the gods of Homer and Virgil, and (for that very reason) far less like the gods of Paganism in its highest religious development. After Milton total degradation sets in and we finally reach the purely consolatory, hence waterishly feminine, angels of nineteenth-century art (LEWIS, 1964, p. 70-72, 74-75, 87).

In sum: Lewis works with the medieval model regarding angelical creatures. His cosmic trilogy reflects such pattern: the eldila and the Oyaresu ${ }^{20}$ are

${ }^{20}$ In his cosmic trilogy Lewis did not invent languages with the richness of details and the sophistication of his colleague J. R. R. Tolkien. Rather, he invented a few words, and sometimes their plural forms: eldila, plural form of eldil, Oyaresu, plural form of Oyarsa. 
intermediate angelical beings between the Most High God and the other intelligent creatures and humans they contacted in outer space (LEWIS, 2005a; LEWIS, 2005b) or here on Earth (LEWIS, 2019c).

It seems the remote root of the understanding Lewis had taken from the Pseudo-Dionysius that there are angels in charge of supervising the stars comes from Jewish religious apocryphal literature. In The Book of the Secrets of Enoch ${ }^{21}$ the angelic supervising activity of the stars by the angels is described as follows:

They brought to me the elders and the rulers of the stellar orders, and they showed me two hundred angels who ruled the stars and theirs functions in the sky, and they flew with their wings and they manifested themselves to all those who navigate (TRICCA, 1989, p. 25, my translation).

Such model of "operation" of the cosmos having planets and stars ruled or supervised by angels that are intermediate between creation and the Creator, which is found in Jewish apocalyptic literature and in some Christian Patristics authors is utilized by Lewis in his cosmic trilogy.

\section{Conclusion}

C. S. Lewis was a profound and paradoxical thinker. On one hand, he was extremely rationalistic. Examples of his rationality are found in some of his books, e.g., The Problem of Pain (LEWIS, 2015a) and Miracles (LEWIS, $2015 b)$. In such books one can find his approach to complex questions the possibility of supernatural intervention the natural world (Miracles) and a problem as old as humankind: why there is suffering in the world (The Problem of Pain). Besides, as one reads Lewis,it is necessary to keep in mind that he was not a systematic thinker, and this helps to understand his "paradoxicality". On the other hand, since his religious experience of conversion from atheism to Christianity in $1929^{22}$ Lewis had become an apologist of Christian faith, using too much and many times the language of imagination and fantasy. He did so due to his understanding that the language of myth is capable of expressing spiritual truths in a more ac-

\footnotetext{
${ }^{21}$ Almost nothing is known about the composition of this Jewish apocryphal book, and it should not to be confused with the well-known Book of Enoch or Ethiopian Book of Enoch. The Book of the Secrets of Enoch, also known as Slavonic Enoch or Slavic Enoch must have be written in the first century before Christ, in Alexandria, a city with a large Jewish colony For more details see, inter alia, ORLOV, 2007.

${ }^{22}$ For a description of the experience of conversion of Lewis the definite work is still his spiritual autobiography: Surprised by Joy (LEWIS, 2017). DOWNING (2006) presents an analysis of that experience.
} 
curate way than a "straight" exposition, so to speak. In other words: Lewis was a rationalist fully aware of the limits of human rationality. Therefore, he used a literature of fantasy and, as it is in the cosmic trilogy, science fiction, but one that cannot be categorized in the established typology of literary criticism, because it is neither hard nor soft science fiction. Coherent to his consciousness of the limitation of human rationality to grasp the greatness of transcendental mysteries, Lewis was critical of the so called LTP, "Liberal Protestant Theology" of German expression ${ }^{23}$. This theology rejects what cannot be demonstrated in a Cartesian way. Lewis is not comfortable with such a model of theology, and criticizes it through literature of fantasy.

In his cosmic trilogy Lewis rescues a theme that was virtually ignored by the aforementioned rationalistic theology of his day: angels, heavenly creatures that, accordingly to a view that goes back to the time of Judaism of the intertestamentary period, that understood them as mediators between God and the world.

In the cosmic trilogy there is plethora of themes that can be analyzed from a theological perspective, as a critique of the myth of progress and rationalism - Weston is the stereotype of the pragmatic scientist who believes only in what can be perceived the physical senses with no moral values or any scruple ${ }^{24}$. Among the conglomeration of theological themes in this narrative, the theme of angelology is perhaps one of the most highlighted. Lewis rescues a theme that is virtually ignored by the theological reflection of his time, and presents it through imaginative literature. His vision of angelology is based on medieval Christian theology with a remote root in the Jewish apocalyptical literature of the intertestamental period.

The launching of one more edition of Lewis's cosmic trilogy in Brazil is capable of allowing room for a rise in the research of Lewisian themes in Brazil, and it will help increase the dialogue between theology and literature (LEWIS 2019a, 2019b, 2019c). May this present article help the achievement of such end.

\footnotetext{
${ }^{23}$ In an ironical and jesting way, The Great Divorce (a book inspired in Dante Alighieri's The Divine Comedy) presents a fantasy about a bus trip that goes from hell to purgatory. One of the passengers in the bus is a liberal Protestant who does not believe in any supernatural spiritual reality (LEWIS, 2006b).

${ }^{24}$ In Weston Lewis presents through literary imagination what he presented in a theoretical way in The Abolition of Man: science and technical information without absolute moral values lead the human being inexorably to destruction (LEWIS, 2001). Weston is a "serious" version of the muddled Uncle Andrew of The Magician's Nephew, one of The Chronicles of Narnia (LEWIS, 1987).
} 


\section{References}

BARTH, K. Esquisse d'une dogmatique. Neuchâtel: Delachaux \& Niestlé, 1968.

BÍBLIA SAGRADA. Traduzida em português por João Ferreira de Almeida. Edição Revista e Atualizada no Brasil. Barueri: Sociedade Bíblica do Brasil, 1993.

BROMILEY, G. W. A. In: ELWELL, W. A. (Ed.). Enciclopédia Histórico-Teológica da Igreja Cristã. São Paulo: Vida Nova, 1988. v. 1, p. 72-74.

COMFORT, P. W. A. In: COMFORT, P. W; ELWELL, W. A. (Eds.) Tyndale Bible Dictionary. Carol Stream: Tyndale House Publishers, 2001. p. 46-47.

COX, S. L. A. In: BRAND, C.; DRAPER, C.; ENGLAND, A. (Orgs.). Dicionário Bíblico Ilustrado Vida. São Paulo: Vida, 2018. p. 83-84.

DOWNING, D. C. Planets in Peril: a Critical Study of C. S. Lewis's Ransom Trilogy. Amherst: University of Massachusetts Press, 1995.

DOWNING, D. C. C. S. Lewis: o mais relutante dos convertidos. São Paulo: Vida, 2006.

HOOPER, W. Prefácio. In: LEWIS, C. S. Sobrehistórias. São Paulo: Thomas Nelson Brasil, 2018.

KOSTERMAIER, K. A Survey of Hinduism. 3st.Ed. New York: SUNY Press, 2010.

LEWIS, C. S. The Discarded Image: an introduction to Medieval and Renaissance Literature.Cambridge: Cambridge University Press, 1964.

LEWIS, C. S. As cartas do Coisa-Ruim. São Paulo: Loyola, 1982

LEWIS, C. S. The Magician's Nephew. London: Harper Collins, 1987.

LEWIS, C. S. The Great Divorce. London: Harper One, 2000.

LEWIS, C. S. The Abolition of Man. London: Harper One, 2001.

LEWIS, C. S. Out of the Silent Planet. London: Harper Collins, 2005a.

LEWIS, C. S. Perelandra. London: Harper Collins, 2005b.

LEWIS, C. S. The Problem of Pain. London: Harper Collins, 2015a.

LEWIS, C. S. Miracles. London: Harper Collins, 2015b.

LEWIS, C. S. On Science Fiction. In: LEWIS, C. S. On Stories. New York: Harper Collins, 2017b.

LEWIS, C. S. A Reply to Professor Haldane. In: LEWIS, C. S. On Stories. New York: Harper Collins, 2017c.

LEWIS, C. S. Surprised by Joy. The Shape of my Early Life. London: Harper Collins, 2017a.

LEWIS, C. S. Além do planetasilencioso. São Paulo: Thomas Nelson Brasil, 2019a.

LEWIS, C. S. Perelandra. São Paulo: Thomas Nelson Brasil, 2019 b.

LEWIS, C. S. Aquelafortalezamedonha. São Paulo: Thomas Nelson Brasil, 2019c.

LINDSAY, M. The heavenly witness to God: Karl Barth's doctrine of angels. Scottish Journal of Theology, Cambridge, v. 70, n. 1, p. 1-18, Feb. 2017. 
MELVIN, D. P. The Interpreting Angel Motif in Prophetic and Apocalyptic Literature. Minneapolis: Fortress Press, 2013.

NKANSAH-OBREMPONG, J. A. In: DYRNESS, W. A.; KERKKAINEN, V.-M. (Orgs.) Dicionário Global de Teologia. São Paulo: Hagnos, 2017. p. 19-23.

ORLOV, A. From Apocalypticism to Merkabah Mysticism: Studies in the Slavonic Pseudepigrapha. Leiden: Brill, 2007. (Supplements to the Journal for the Study of Judaism, 114).

REBLIN, I. A. Quando os deuses morrem na praia: algumas anotações sobre anjos e textos sagrados. Ciberteologia, São Paulo, Ano 6, n. 28, p. 61-70, mar./abr. 2010.

SCHÖKEL, L. A. Anjo. In: Dicionário bíblico hebraico-português. São Paulo: Paulus, 1997. p. 376-377.

SHIPPEY, T. Light-elves, Dark-elves and Others: Tolkien's Elvish Problem. Tolkien Studies, Morgantown, v. 1, n. 1, p. 1-15, 2004.

TAVARES, B. O que é ficção científica. São Paulo: Brasiliense, 1986. (Coleção Primeiros Passos).

TODORO V, T. Introdução à literatura fantástica. São Paulo: Perspectiva, 2012.

TRICCA, M. H. de O. O Livro dos Segredos de Enoch. In: TRICCA, M. H. de O. Apócrifos: osproscritos da Bíblia. São Paulo: Mercuryo, 1989.

WESTERMANN, C. O anjo de Deus não precisa de asas. 2.ed. São Paulo: Loyola, 2017.

WILSON, S. L. A Mythical Approach to Christian Orthodoxy: C. S. Lewis's Space Trilogy. Thesis (Degree of Master of Arts in English). Lehigh University, Bethlehem, 1977.

Article submitted in 28 Aug 2019 and accepted 07 Apr. 2020.

Carlos Ribeiro Caldas Filho received his doctorate (Ph.D.) in Religious Studies from Universidade Metodista de São Paulo (São Paulo Methodist University) and has done a post-doctoral research in Theology at the Faculdade Jesuíta de Filosofia e Teologia (Jesuit School of Philosophy and Theology) in Belo Horizonte. He is Lecturer at the Post-Graduate Department of Religious Studies of Pontifícia Universidade Católica de Minas Gerais (Pontifical Catholic University of Minas Gerais State) in Belo Horizonte. Orcid.org/0000-0003-0472-7250. E-mail: crcaldas2009@hotmail.com

Address: R. Artur Prado, 389 /Apto 114

Bela Vista

01322-000 São Paulo - SP 